\title{
Measuring the biological impact of drilling waste on the deep seafloor: an experimental challenge
}

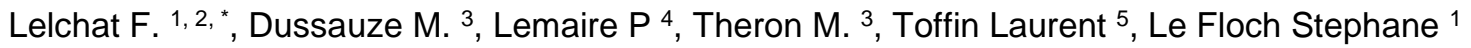

${ }^{1}$ Cedre, 715 rue Alain Colas - CS 41836, 29218 Brest CEDEX 2, France

2 Leo viridis, 140 Avenue Graham Bell, 29280 Plouzané, France

${ }^{3}$ EA 4324 ORPHY, Université de Bretagne Occidentale, Université de Brest, 6 avenue LE GORGEU, CS 93837, 29238 Brest cedex 3, France

4 TOTAL FLUIDES SAS, 24 cours Michelet - 92800 Puteaux, 342241908 RCS Nanterre, France

5 Laboratoire de Microbiologie des Environnements Extrêmes, UMR6197, Ifremer Centre de Bretagne,

ZI de la pointe du diable, CS 10070, 29280 Plouzané, France

${ }^{*}$ Corresponding author : F. Lelchat, email address : lelchat@leoviridis.fr

\begin{abstract}
:
The depletion of traditional oil fields is driving the oil \& gas industry to explore new exploitation sites previously considered as unprofitable. Deep-sea oil fields represent one of these new areas of exploitation. Well drilling during exploration and production operations generate large quantities of drilling waste whose biological impact on the deep-sea floor remains largely unknown. Because of the harsh abiotic factors characterizing this environment, the evaluation of this impact remains challenging. High hydrostatic pressure is the prominent factor which will affect in-situ biological processes. This review will examine the feedback on the various strategies used to evaluate the biological impact of deep-sea drilling waste deposition as well as the current technological limitations. Given the complexity of this issue, a good perspective strategy would be to trend towards the research and development of more relevant bioassays, especially considering the crucial factor of hydrostatic pressure.
\end{abstract}




\section{Graphical abstract}

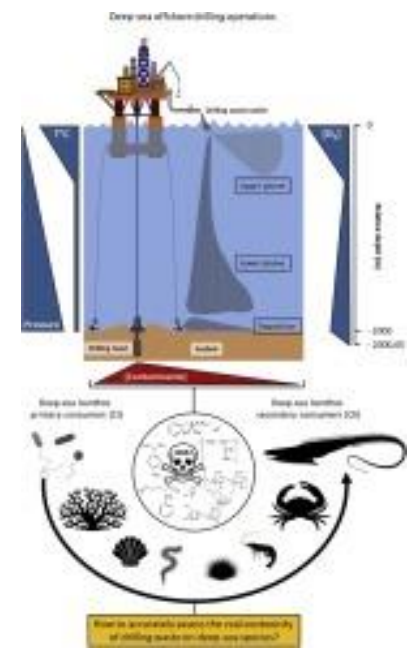

\section{Highlights}

Deep-sea offshore drilling operations generate byproducts known as drilling waste. Worldwide environmental regulations on drilling waste discharges constantly harden. The environmental impact of drilling waste on deep-sea ecosystem is largely unknown. High hydrostatic pressure greatly complicates environmental investigations. R\&D on new pressurized bioassays is needed to assess of these potential impacts.

Keywords : drill cutting, drilling waste, ecotoxicology, bioassay, hydrostatic pressure, deep-sea, environmental assessment 


\section{- Introduction}

Recent estimates suggest that one third of the global oil production comes from offshore infrastructures (Maddahi \& Mortazavi, 2011). The worldwide demand increase drives constant technological innovations, which allow exploring and exploiting in increasingly deep-water oil fields (IEA 2013, Merrie et al., 2014). Offshore exploration and production activities for the oil and gas industry mainly generate two kinds of byproducts without commercial value: produced water and drilling waste. Excepted accidental releases (e.g. leakage), they are the main source of hydrocarbon discharges during offshore operations. The environmental impact of produced water is long known and well documented (Malachosky et al., 1993; Kingston P., 1992; Bakke et al., 2013). Study cases on drilling waste are not rare but still limited, particularly for more unusual drilling scenarios such as deep-water operations). 
Drilling waste comprises 2 categories: drill cuttings and spendt drilling muds (Veil JA., 2002; Ellis et al., 2012; Cochrane et al., 2019).

Drilling muds are the compounds and fluids that are injected into the borehole to facilitate the drilling process, for example to lubricate and cool the drill bit, assist the upward transport of drill cuttings and also for hole stabilization. Three main types of drilling muds exist:

- Oil-based mud (OBM) mainly composed of oil or diesel.

- Synthetic-based mud (SBM) whose composition is based, for example, on ester, ether, acetyl or olefin.

- Water-based mud (WBM) also called water-based fluid (WBF) using in situ water (fresh or seawater).

Other compounds typically added to the mud for weighting and other enhancing properties include clay (e.g. bentonite), ilmenite $\left(\mathrm{FeTiO}_{3}\right)$, barite $\left(\mathrm{BaSO}_{4}\right)$, organic polymers, inorganic salts and various organic additives (Breuer et al., 2004).

The release of drilling waste has a number of consequences from both practical and financial viewpoints as well as in terms of environmental issues. The type and amount of discharges vary according to the type of drilling operation (e.g. exploratory or production) and the site-specific characteristics such as geographical properties and water depths as well as reservoir location and structure. In addition, local legislations will dictate how the waste is to be handled; whether it will be deposited at source-point, translocated on the sea floor, dispersed at the sea surface - or whether at least some of it must be taken to land. Furthermore, the environmental and socio-economic considerations are constantly evolving, especially as the industry is moving into new areas such as the Arctic and the deep sea. As a result, both the industry and the environmental regulatory authorities face a myriad of challenges to which there currently is no single, unified answer.

The present study will present a brief review of the different aspects related to offshore drilling waste from the oil and gas industry, with particular emphasis on deep-sea operations (> $750 \mathrm{~m}$, sensu ISO 16665). We will examine the various tools currently used to study environmental impacts on the sea-floor and assess their relevance to the particular challenges arising as drilling operations inevitably move into increasingly deeper locations, also within the context of the prevailing environmental legislations. 


\section{- Legislative framework}

The Montego Bay Convention (CMB) and the Marpol convention are historical and globally recognized agreements on the protection of the oceans. They nevertheless do not provide a fully clear, complete and functional legislative framework to regulate offshore oil \& gas exploration/production activities (Durand A., 2014). These activities generally take place on the continental shelf or within the 200 nautical mile limit from the margin (exclusive economic zone: EEZ). The administration of the continental shelf and EEZ comes under the responsibility of the corresponding coastal state. De facto, national or regional laws prevail for the legislation of such offshore activities. To limit negative impacts on the marine environment, drilling waste releases are increasingly under strict regulation. Nevertheless, without unifying international agreement legislation, tolerance variations between countries hosting exploitation sites are common (IOGP report, 2016). Existing regulations mainly target releases of chemicals like metals, additives not derived from hydrocarbon and hydrocarbons.

In the following section, we will examine concrete examples of the most advanced laws and regulatory systems around the world (national and regional) to depict the major environmental management philosophies. These examples are also summarized in the table 1.

The US legislative framework follows the United States Environmental Protection Agency (USEPA) regulations. This is a proteiform approach with no real constancy between oil and gas exploration/production cases/regions/states. It can be considered as pragmatic exploitation of local legislative specificities. For example, regulatory approaches will be dramatically different between oil and gas development areas of the US part of the Gulf of Mexico (bordered by the states of Florida, Alabama, Mississippi, Louisiana and Texas) and the Alaskan part of the Chukchi Sea (IOGP report, 2016). Thus, USEPA regulations, designed to avoid a "compliance burden" for industries, can be considered as a variable geometry legislative framework (Menzie CA, 1982; Rana S., 2010). Canada also follows such a system through the involvement of institutions like the C-NLOPB (CanadaNewfoundland and Labrador Offshore Petroleum Board). A similar system exists in Australia where states' and territories' law agreements prevail over federal and Commonwealth legislations (Filder \& Noble, 2012; Fraser et al., 2008).

In northern Europe, the vast majority of offshore infrastructures are located in the North Sea (NS) (Purser \& Thomsen., 2011), with increasing activity in the Norwegian Sea and the south-western 
Barents Sea. In more southern regions, some minor fields exist in the Adriatic Sea, off the Sicilian coasts and in the Balearic Sea (Pinder D., 2001). European legislation has the highest level of requirement in comparison with the rest of the world (Durand A., 2014). For example, in Norway, since 2001 OBM and subsequent drill cuttings are no longer permitted to be released at sea. If the concentration of hydrocarbons $(\mathrm{HC})$ in sand, mud and cuttings exceed $10 \mathrm{~g}^{\mathrm{kg}}{ }^{-1}$, they are systematically recovered and shipped to shore for land disposal (Nguyen et al., 2018). This kind of approach is mainly based on the "precautionary principle" and the "polluter pays principle" that were initiated with Helcom (Helsinki Commission) in the 1980s for the Baltic Sea (despite its low available hydrocarbon reserves) as well as with the OSPAR (Oslo-Paris) convention in the early 1990s for the North-Eastern Atlantic (Ekins et al., 2007). They clearly aim at a generalization of the aim of zero harmful discharges to the sea by 2020 (Knol M., 2011), which is also in line with the European Union's Marine Strategy Framework Directive (MSFD), which states that all the European seas should attain Good Environmental Status (GES) by 2020. It has to be highlighted that this legislation considers only hazardous discharges without concern for conventional discharges. Similar systems with a comparable degree of requirement are also operating for the Mediterranean Sea, with the Barcelona Convention and its offshore protocol, as well as for the Persian Gulf via the Kuwait Regional Convention for Co-operation on the Protection of the Marine Environment from Pollution (Durand A, 2014). It is worth noting that the most advanced law agreements on offshore operations all concern very limited geographical areas. In the future, it is reasonable to expect a worldwide trend toward standardization of such procedures. Therefore, in a perspective of ecological and economical ongoing relevance, in accordance with the Porter hypothesis (commercial competitiveness is positively driven by environmental regulations through innovations) (Ambec et al., 2013), current and new processes used for exploration/production in the oil \& gas industry must overtake these probable evolutions.

\section{- General ecological impacts}

The ecological impact of drilling waste is mainly linked to its spatial behavior after emission at sea (if so). This behavior is determined by its physicochemical properties (composition, density, size of particular material, solubility), the total depth of the water column as well as the speed of the dominant stream (or local energy regime). Finally, the total volume of discharged waste will also deeply influence the deposition phenomenon, especially with deep well mining. During emission, drilling waste will split into two plumes: 
- An upper plume containing low density, small sized and rapidly dissolving material (mainly drilling fluids) whose patch diffusion speed is a function of the surface stream and upper water column.

- A lower plume based on drill cuttings which will settle to, and accumulate on, the sea bottom.

From an ecological perspective, the lower plume will have a stronger impact on the ecosystem through the durable formation of a drill cuttings pill on the sea floor. The deposition of this waste pill can be simulated according to environmental and the drill cuttings' physicochemical parameters. By convenience, the physicochemical properties of drill cuttings can be condensed to their overall lift in the water column. The water column depth and the dominant stream are the main two environmental parameters. The morphology of drill cutting deposition will be the resulting barycenter of these 3 forcing parameters as a function of their respective intensities (Figure 1). The accumulation of drill cuttings will durably alter the physicochemical properties of the sea floor (Breuer et al., 2004). The waste pill will mainly generate a rapid microbial-driven anoxia of the sediment followed by decreased redox potential and release of exogenous compounds (e.g. heavy metals, hydrocarbon). These changes will consequently impact the seafloor biocenosis from the microbiota to the fauna.

\section{- Known impacts on the benthos}

The impact assessment of contaminated or uncontaminated drill cuttings on benthic ecosystems is the result of three approaches: a physico-chemical analysis of the sediment (redox parameters, Size Exclusion Chromatography for polymers, Gas chromatography for hydrocarbons...), an ecological analysis of benthos (both meiofauna and macrofauna) and an ecotoxicological analysis using key species of macrofauna (annelids, nematodes, molluscs and crustaceans) (Jorissen et al., 2009).

Due to the strong biological impact observed with oil-based muds (OBM), oil-based fluids (OBF) is now not currently applied and requires special agreement to be used (Hurley \& Ellis, 2004). Indeed, OBM impact assessment demonstrated large-scale release with an increase in barium and total hydrocarbon concentrations in sediment located 2000 to $6000 \mathrm{~m}$ from the platforms. The major problem is the persistent impacts on benthic communities (Olsgard \& Gray, 1995; Daan et al., 1996), with composition change such as the loss of rare species and an increase in pollution-tolerant species (Gray et al., 1990; Olsgard \& Gray, 1995) and/or opportunistic species (Davies et al., 1984). 
According to the review of Eliss et al. (2012) on sediment barium concentrations, water-based drilling fluids have a higher chemical impact than synthetic-based fluids, with an influence zone from 2 to $20 \mathrm{~km}$ and 0.2 to $2 \mathrm{~km}$, respectively for WBF and SBF. Benthic ecosystems are impacted by both WBF and SBF at a distance of 100 to $1000 \mathrm{~m}$ from the well. As for OBFM, alterations in diversity, abundance and structure are reported in benthic community (Netto et al., 2009; Eliss et al., 2012). Evidence of sediment impact on benthic communities is highlighted by the loss of suspension feeders, and an increase in deposit feeders and polychaetes. This visual evolution is particularly striking and demonstrates one of the major environmental impacts of drilling activities is the increase in suspended sediments in the deep-sea bottom and its relation to physical changes in substrate (Netto et al., 2009).

Bottom current is a natural conveyor of suspended sediment. In the Norwegian shelf (White et al., 2012), an important area for oil and gas operations in the North-East Atlantic, drillings lead to an increase in sediment suspension and drift toward suspensivorous-specific ecosystems like deep-water coral reefs. Deep-water coral reefs are considered as biodiversity hotspots (Roberts et al., 2006) sheltering hundreds of associated organisms which cover almost every phylum (Rogers 1999). Consequently, they have a crucial role in deep benthic ecosystems. Anthropic activities have reported effects on deep-water coral reefs (Roger, 1999). For example, a direct destructive effect is caused by bottom trawling by fisheries (Althaus et al., 2009). Nevertheless, most anthropic effects on deep-water scleractinian coral reefs are indirect and the consequence of an increase in suspended sediment (Pilskaln et al., 1998; Lepland \& Mortensen, 2008; Trannum et al., 2010). Impact assessments of drilling activities on deep-water corals have long studied this issue, with different levels of coral organization and timescales (see below). One of the major species of framework-forming deep-water coral builder is Lophelia pertusa (Freiwald, 2002; Roberts et al., 2009). L. pertusa can be relatively tolerant, in lab conditions, to short term exposure to drill cuttings and natural sediment (Larsson \& Purser, 2011). Bausant et al. (2018) determined a threshold drill cutting concentration of $10 \mathrm{mg}^{-1}$ (with particles smaller than $63 \mu \mathrm{m}$ for $97 \%$ of them), above which, changes in coral polyp behaviors were observed. Under high sedimentation, L. pertusa exhibited resilience to hypoxic, and even anoxic, episodes (Allers et al., 2013). Due to its ability to endure anoxia only for a short time and the slow recovery after this stress episode, Allers et al. (2013) suggest an anoxia tolerance rather than an anaerobic metabolism. So, we can assume that a part of the L. pertusa mechanism to cope with hypoxia and anoxia is probably present in their mitochondria. 
Research efforts should now point out these mechanisms and analyze the respiratory chain of the coral model, like L. pertusa, after exposure to sediment or polluted sediment. In particular, they should examine the possibility that mitochondrial alterations may not have any effect at a higher level of integration (e.g. polyp behavior). This compensation phenomenon is recognized and probably hides some fitness changes. Indeed, the compensation phenomenon has an energetic cost and could have a major effect of organism ontogenesis, as described by Hsing et al. (2013) during a 17-month study following the DeepWater Horizon oil spill. Using remoted operational vehicles (ROV), the authors performed environmental monitoring on deep-water corals contaminated by oil-polluted flocs. They demonstrated the long-term impact of oil contamination on corals by observing the modification of coral colonies which were more and more colonized by hydroid fouling. The short-term impacts seemed to be relatively low. However, the effects which continued for months led to the reduction of coenosarc tissue and the onset of opportunistic species on the newly apparent coenosteum. Godø et al (2014) tested a methodology to obtain real time observation system for monitoring the potential environmental impact of drilling operations. The system is a coupling sensor platform (optical and acoustic) with a surface communication buoy. As mentioned by authors, the experimental system requires some improvements, but could offer in the future a relevant way to assess the environmental impact during all phases of drilling operation and also between several drill sites. In the same purpose, Purser (2015) performed a relevant monitoring studies of potential impact of drilling activities on small size $L$. pertusa reefs in the Morvin field (350m depth) located in the Norwegian margin. Using several ROVs, nine coral reefs were video surveyed before, during, immediately after and one year after drilling activities. Modeling of drill cutting transport following releases allowed the author to generate three levels of reef exposure: negligible, occasional exposures $(>5 \mathrm{ppm})$ or repeated exposures $(<5 \mathrm{ppm})$. Author reported no observation of modification of the reef structure and associate megafauna abundance over time whatever the modelled exposure concentration. However, this study only focused his survey on adult fauna and the question of larvae behavior in drilling activities context is worrying. Indeed, Järnegren et al. (2017) have demonstrated than adult L. pertusa can survive with high sediment load. However if the same high sediment load occurs during larval time, it will kill all or the major part of the larval cohort. This study demonstrated the deleterious effect that a major discharge of sediment in deep-sea ecosystem could have during coral spawning time. 


\section{- Reported impact on microflora}

Similarly to benthos, deep seafloor microflora will be dramatically impacted by drilling waste release. Nevertheless, comparatively to benthic zoocenosis, very few extensive studies have been conducted on sediment microbiota. Most of the in situ studies focus on the biogeochemical modification of the sediment as well as the biodegradation of hydrocarbon and/or drilling fluids. Notably, metagenomic approaches on drill cutting are still scarce compared to more classic studies e.g. hydrocarbon impacted shore. Reported studies point out a seafloor bacterial community shift in cases of drilling waste deposition (Main et al., 2015; Nguyen et al., 2018). This shift is accompanied by biogeochemical perturbation affecting the $S$ and $\mathrm{N}$-cycle (King et al., 2015) and a rapid decrease of dissolved oxygen (36h, Main et al., 2015) leading to localized anaerobic spots (Nguyen et al., 2018) and a potentially strong redoxcline (Schaanning et al., 1997; Trannum et al., 2011). Microbial community restructuration is also marked by a functional shift toward an enrichment of the hydrocarbon anaerobic metabolism repertoire (King et al., 2015). Interestingly, this means that some phylogenetic groups can be used as microbial bioindicators (Nguyen et al., 2018) like proteobacteria clade (Napp et al., 2018). The real impact of deep-sea abiotic factors (hydrostatic pressure, low temperature, anaerobicity) is not clear but at least they seem not to inhibit drilling waste biodegradation by indigenous microbiota (Nguyen et al., 2018). As mentioned above, exhaustive studies into the impact of drilling waste on the seafloor microbiota, especially on community structuring, remain anecdotal. To fill this gap in knowledge, some parallels can be drawn with studies about the impact of hydrocarbon pollution on deep-sea floor microbiota. Initiated after the Macondo blowout (MBO) in 2010, numerous results from the Gulf of Mexico Research Initiative (GOMRI) perfectly illustrate this (http://gulfresearchinitiative.org/). During this major environmental crisis, the authorities authorized the intensive use of Corexit 9500 to disperse and stimulate the microbial biodegradation of the accidentally released crude oil (Azwell et al., 2011). Biodegradation of hydrocarbons always starts by the simplest compounds, e.g. short chain alkanes (Heads et al., 2006). In the case of the MBO, the biodegradation of small compounds in previously dispersed oil led to oil sedimentation promoted by marine oil snow formation and flocculants accumulation (MOSSFA) (Ramseur, 2010; Passow et al., 2012; Nguyen et al., 2018; Brooks et al., 2015). This "dirty blizzard hypothesis" was simulated by ex situ lab experiments and proven to be a microbially driven phenomenon (Passow et al., 2012). In many ways, this contamination of the 
environment by MOSSFA can be related to pollution with drilling waste. In both cases, a dual emission plume is observed (IOGP report 2016, Daly et al., 2016) (Figure 2).

That is particularly interesting considering the vast range of bathymetric profiles impacted which can be used to virtually assess the potential effect of drilling waste according various technical scenarii. Like for drilling waste, MOSSFA deposition enriches the seafloor with organic or inorganic pollutants but also generates microbial seeding with strains from the water column and deep-biosphere (Joye et al., 2014; Arnosti et al., 2016; Mason et al., 2012, Mason et al., 2014). Due to the intense and focused nature of the $\mathrm{MBO}$, effects on the microbiota were different from natural hydrocarbon seepage, characteristic of a prolific hydrocarbon basin such as the Gulf of Mexico (Joye et al., 2016). These seeps are natural biodiversity hotspots with well-adapted interdependent biological communities from microbial to deepsea animals (Cordes et al., 2009). MBO dramatically impacted deep-sea and shoreline communities (White et al., 2012; Fisher et al., 2014a; Fisher et al., 2014b, Silva et al., 2016). Similarly to drilling waste, widespread deposition of MOSSFA generated sedimentary biogeochemistry changes. Perturbations of the $\mathrm{N}$ and S-cycles were reported (Joye et al., 2014). Hastings et al. (2016) also reported changes in sediment redox conditions following the MBO event with a decrease in the pore water oxygen concentration and a shoaled redoxcline for 3 years before a gradual return to pre-impact values. A metagenomic and metabolic survey of the sedimentary microbial response to MBO pointed out temporal and spatial biodegradation patterns (both in term of localization in the gulf and in the sedimentary column). These patterns are mainly linked to the nature of the hydrocarbon contaminants and oxygen bioavailability. Briefly, Deltaproteobacteria (e.g. Desulfatibacillum $s p$ ) were involved in anaerobic biodegradation of aliphatic and aromatic hydrocarbons in the first months after the spill and subsequent MOSSFA deposition (Mason et al., 2014). At the same time Gammaproteobacteria (e.g. Oceanospirillales such as Alcanivorax $s p$ ) were involved in the aerobic biodegradation of $n$-alkanes, aliphatic and simple aromatic hydrocarbons (Mason et al., 2014). Alphaproteobacteria (e.g. Roseovarius spp) were able to aerobically degrade more recalcitrant aromatic oil compounds such as PAHs (Kotska et al., 2011; Kimes et al., 2013). Interestingly, these trends, although perfectible, seem independent of hydrostatic pressure. For experimental and economic reasons, ongoing research should assess this point using long time scale pressurized microcosm experiments. Indeed, enrichment culture with native piezophile and piezotolerant communities on a simulated and stabilized sea bottom could more accurately highlight communities and functional shift during drilling waste/MOSSFA biodegradation. 


\section{- Pressurized biological assay: experimental background and technical challenges.}

The industrial exploitation of the deep-sea bottom can lead to waste production and consequently to potential environmental risks. As required by the legislation (e.g. OSPAR convention in the North-East Atlantic), these risks, or in the worst case the pollution, must be assessed using several methods including ecotoxicological tests, also known as bioassays. Since bioassays never reflect the full reality of the field, their ecological relevance is questionable; they nevertheless still offer an elegant way to assess the relative toxicity of chemicals in the environment. To be ecologically coherent, bioassays must consider several abiotic parameters, such as temperature, salinity or $\mathrm{pH}$, variable parameters of water ecosystems.

In aquatic environments, hydrostatic pressure depends on the height of the water column and hence increases linearly with depth. At $2000 \mathrm{~m}$ under the ocean surface the pressure is close to 200 tons per square meter (202 bars). About $70 \%$ of the ocean (Parkes et al., 2009) is made up of deep-sea environments with an average pressure of 380 bars and up to 1100 bars in the sediment layer of the Mariana Trench. Hydrostatic pressure is, like temperature, a thermodynamic parameter of the environment. Increasing hydrostatic pressure favors the state of smaller volumes and hydrostatic pressure is liable to influence a huge number of fundamental biological structures and processes including macromolecular properties (Johnson et al., 1974; Kunugi,1992), biochemical reaction rates and equilibrium (Johnson \& Eyring, 1970, Somero, 1991) or biological membrane fluidity (Macdonald 1984). Furthermore, hydrostatic pressure interacts with other fundamental factors of the environment and in particular with temperature and osmotic pressure (Kornblatt \& Kornblatt, 2002; Sébert et al., 2004; Hochachka, 2005, Yancey, 2005). For these reasons, the effects of hydrostatic pressure on biological systems are too important to be set aside or, worst, extrapolated from atmospheric pressure results.

Hydrostatic pressure is one of the most difficult abiotic parameters to control in the laboratory. It requires specialized equipment and expensive maintenance. Consequently, literature on bioassays at simulated depths is scarce. Furthermore, bioassays under pressure must meet a number of criteria to be relevant. In addition to being able to control the hydrostatic pressure, the bioassays should be easily applicable within a short timeframe. An ideal test would be suitable to respond to a routine request for environmental monitoring as well as in an emergency context in case of deep-water pollution. To be 
economically viable, the experimental device should require limited maintenance between trials. Finally, a comparison with a standardized bioassay usually used at atmospheric pressure would be a plus in order to monitor continuity in different ecosystems ranging from bathyal to coastal zone.

\section{- Animals assay}

Deep-sea ecotoxicological studies (hereafter referred as eco-piezotoxicological studies) are a new field for the assessment of anthropic effects. Data are still scarce and several approaches are used to explore this new issue (Lemaire et al., 2017). One of these approaches uses piezotolerant species brought from the deep-sea and exposed to chemicals at atmospheric pressure. This was performed on several taxa of different trophic levels, such as deep-sea coral (see Benthos report impact section), a giant deep amphipod Eurythenes gryllus (Olsen et al., 2015; Camus \& Gulliksen, 2005) and sablefish Anoplopoma fimbria (McConville et al., 2018)

Boschen et al (2013) highlighted, in a review about the mining of deep-sea seafloor massive sulphides (SMS), the need of relevant bioassays to assess the potential impact of these SMS mining on the benthic fauna. Such bioassays should avoid using shallow water species that do not naturally face "extreme" abiotic parameters such high hydrostatic pressure, total darkness and/or cold water. Nevertheless, the use of piezotolerant shallow-water species could offer a relevant compromise for the chemical or anthropic impact assessments in deep-sea environments. Indeed, several ecopiezotoxicological studies have been performed under high hydrostatic pressure using hyperbaric chambers: on an intertidal and sub-littoral polychaete Pomatoceros lamarcki exposed at 101 and 304 bars (Vevers et al., 2010), on an European marine shrimp Palaemon varians at a range from 100 to 400 bars (Domingues, 2015), on a demersal fish with seabass Dicentrarchus labrax at 138 bars (Dussauze et al., 2017) and at 50 and 150 bars (Lemaire et al., 2016) and a benthic fish, turbot Scophthalmus maximus at 101 bars (Dussauze et al., 2016; Dussauze et al., in prep). Kopecka-Pilarczyk \& Coimbra (2010a; 2010b) investigated the effect of pressure on relevant ecotoxicological biomarkers on the liver (EROD, GST, CAT, SOD, Lipid peroxidation...) of a shallow water fish Pagellus bogaraveo (KopeckaPilarczyk \& Coimbra, 2010a) and on European eel Anguilla anguilla (Kopecka-Pilarczyk \& Coimbra, 2010b). This last study is interesting due to the choice of the model species. The European eel has a life history containing a deep-sea phase. This led to the final and more relevant approach, but which is also more difficult, consisting in analyzing deep-sea species under simulated depth. Lemaire et al. 
(2012) pressurized liver slices of rock grenadier Coryphaenoides rupestris fished at 530 meters depth at 1, 50 and 150 bars. To date, in vitro tools coupled with a hyperbaric chamber (Lemaire et al., 2012; Dussauze et al., 2016) seem to offer the best compromise between ecological relevance and cost of experimentation in eco-piezotoxicology.

Depressurization and pressurization remain the major issue in eco-piezotoxicology. Repetitive pressure changes have been shown to alter the oxygen consumption of deep-living fish (Roer et al. 1984). The effects of pressure changes were also investigated by Theron and Sébert (2003) on mitochondrial and cellular respiration on the European eel acclimatized at atmospheric pressure or at 101 bars, showing that pressure changes strongly affect aerobic metabolism. Nevertheless, the effects of depressurization and pressurization (300 bars) were studied on the hydrothermal vent shrimp Rimicaris exoculata after copper exposure (Auguste et al., 2016). The results of this study suggest that the biomarkers' responses to metal exposure in shrimps were not affected by several depressurizationpressurization cycles in comparison with in situ results on the same species.

Finally, The use of species performing Diurnal Vertical Migration could avoid the problem of depressurization-pressurization effects due to their adaptive capacities to living at several bathymetries. Zooplankton species such Calanoid copepods could fit for such a pressure bioassay. Their life histories are known for many species and can be easily controlled in a lab. Given their size, they can be used in mini hyperbaric chamber as developed by Dussauze et al. (2016) which requires little maintenance. Furthermore, a correlation with a standardized bioassay could be made with the copepod Acartia tonsa, a model species of an ISO protocol and recommended for the OSPAR protocol.

Finally, as described by Boschen et al. (2013), the adaptation of bioassays under pressure focused on several trophic levels or performed them in situ using ROV could generate relevant biological and ecological data on the chronic and accumulative potential impacts of an anthropic activities in deepsea and therefore how to mitigate them.

\section{- Microbiological assay}

The majority of sub-seafloor microorganisms live under high hydrostatic pressure, and are likely to be well suited to high pressure considering its dramatic effects on microbial viability and growth (Yanagibayashi et al., 1999). Moreover, deep-sea sediments are unique environments in which 
hydrostatic pressure has an impact on the concentration of gases (e.g. $\mathrm{CH}_{4}, \mathrm{CO}_{2}$, other short hydrocarbon gases, $\mathrm{H}_{2} \mathrm{~S}$ ). Cell membranes are often the first barrier affected by hydrostatic pressure which will decrease membrane fluidity concomitantly with pressure increase. Ecophysiological adaptation to high hydrostatic pressure drives microorganisms to increase the proportion of unsaturated fatty acids in their cell membrane to maintain sufficient fluidity (Mangelsdorf et al., 2005). Water content is also an important factor in the inactivation of microbes under high pressure. Vegetative cells are more sensitive to high pressure than spores. High pressure affects the physiology and biochemistry of cells by decreasing the stability of protein folding and hindering the ability of enzymes for metabolic activities.

In response to high pressure, microorganisms growing optimally at pressures above 100 bars (corresponding to a depth of $1000 \mathrm{~m}$ ) are piezophilic or those tolerating elevated pressures are piezotolerant. Obligatory piezophilic microorganisms grow only at elevated pressures. These pressureadapted microorganisms are unable to survive decompression within hours. During sampling at depth, potential damage and/or inactivation of cells due to the depressurization of samples can occur when atmospheric pressure is reached. These effects increase for microorganism of the deep-biosphere where microorganisms are subjected to both hydrostatic and lithostatic pressure. That is probably one of the reasons why strict pieziophilic microorganisms have not yet been isolated from deep-sea sediments in comparison with other deep environments.

Early in the infancy of marine microbiology, deep-sea microbial diversity was explored during series of oceanographic cruises known as the "Travailleur" and "Talisman" expeditions with a French "marine" microbiologist Adolphe-Adrien Certes who first provided protocols for the collection of microbial samples and conducted cultivation of microbial populations from waters and sediments collected at depths ranging from 927 to $5100 \mathrm{~m}$ (Certes, 1884). Later, the pioneering work of two American microbiologists Claude Zobel and Richard Morita in the 1950s (Zobell, 1952) demonstrated using avant garde sophisticated samplers that microbial activity in deep-sea sediments was very low at in situ conditions (i.e. low temperature, high pressure and low nutrient levels). All the techniques used (in situ incubation, aboard ex situ incubation with or without decompression of samples) led to the same observation: organic matter degradation was slower at hydrostatic than atmospheric pressure, suggesting that the microbes probably originated from the surface instead of the deep sea or, at least, that only the piezotolerant species survived the depressurization. This kind of results was again recently 
confirmed by a study on depressurized deep-sea GoM bacterial communities recovered from Niskin Bottles and subjected to an onboard pressurized bioassay with oil from the MBO (Marietou et al., 2018).

This pioneering work pointed out that to obtain a representative overview of deep-sea microbial communities, pressure is a crucial factor. An isobaric approach with samples from the deep-sea environments is essential and yet challenging because changes in pressure and temperature can result in substantial out-gassing that destroys the structural integrity of the sample as well as altering the composition and the activity of its microbial communities. This has been supported by contemporary studies systematically showing that microorganisms from enrichment cultures of depressurized samples are different to those detected by molecular approaches directly from pristine samples (Yanagibayashi et al., 1999; Edgcomb et al., 2016). In the case of a hypothetical study about the consequences of severe anthropogenic perturbation like drilling waste deposition, there is no reason to expect a different outcome. Consequently, deep-sea microbiological bioassays thrive with a recurrent issue, namely: the incubation of piezophilic microorganisms in relevant and uninterrupted deep-sea environmental conditions (temperature, $\mathrm{pH}$, hydrostatic pressure, and oxygen partial pressure - $\mathrm{PaO}_{2}$ ). To overcome these subsequent technical constraints, pressurized microbiological bioassays evolved following 3 strategies:

- Ex situ incubation with an indigenous consortium

- In situ incubation with an indigenous consortium

- Cultivation of pure piezotolerant strains

In the second half of the $20^{\text {th }}$ century, sophisticated devices or prototypes were developed to collect water, fluids, sediments and animals as well as to cultivate microbes inhabiting such ecosystems (Gundersen \& Mountain, 1972; Jannasch et al., 1982; Yayanos, 1978; 1986; Yayanos et al., 1979; 1981; Yayanos \& Dietz, 1983). Pressurized microbiological bioassays are directly derived from these technologies.

Ex situ incubation with a local consortium

Derived from the first deep-sea bioprospection tools, ex situ incubation protocols were developed before in-situ protocols. The reasons are diverse and include the need for direct observation 
driven by naturalistic curiosity, technological limitations and initial ignorance as well as incomprehension of ecophysiologically piezosensitive microbial communities.

Bianchi et al. (1999) expanded the pioneer concept of Jannasch and colleagues (Jannasch et al., 1973; Jannasch \& Wirsen, 1977; 1984) into a multi-chamber setup that allows up to eight pressurized samples to be taken together during a single deployment. The first pressurized deep-sea sediment cores were obtained in 1995 at the Black Ridge and Carolina Rise during the Ocean Drilling Program (ODP) cruise (Leg 164) using the Pressure Core Sampler (PCS), a device that is capable of maintaining in situ pressures of up to 690 bars (depth of around $6900 \mathrm{~m}$ ) (Francis, 2005). In 2003, the Multi-AutoclaveCorer $(M A C)$ and the Dynamic Autoclave Piston Corer $(D A P C)$ were deployed in relatively shallow gas hydrate-bearing sediments in the northern Gulf of Mexico. These devices retrieved, for the first time, near-surface sediment cores under pressure. The systems were designed to recover sediment cores at in situ pressures of up to 142 bars and 304 bars respectively (Heeschen et al., 2007). In addition, deepsea shallow sediment samples (around $5 \mathrm{~mL}$ ) obtained by the manned submersible Shinkai 6500 with a scoop have been successfully brought to the surface in a pressure- and temperature-retaining device (Kato, 2006). Subsequently, enrichment cultures were obtained without decompression (Yanagibayashi et al., 1999) in a large laboratory high-pressure culture device called the "DeepBath system" (Kato, 2006). The importance of obtaining uncontaminated microbial samples led to the development of the Autonomous Microbial Sampler $(A M S)$, which guarantees that uncontaminated fluid samples can be obtained for microbial and nucleic acid analyses from a variety of environments, including deep-sea hydrothermal vents characterized by steep biogeochemical gradients (Taylor et al., 2006). The AMS protects samples against temperature changes, but does not maintain the in-situ pressure. Parkes et al. (2009) developed a system known as Deep-isoBUG which maintains sediment samples under elevated pressure without decompression (up to 250 bars) for enrichment and isolation of microorganisms at pressures of up to 1000 bars. Deep-isoBUG is a subsampling transfer system, which could be coupled with the pressure-retaining core drilling system HYACINTH (Schultheiss et al., 2006; Alain et al., 2014) and the PRESS core-cutting system (Parkes et al., 2009). These systems allow sub-seafloor sediment samples to be sub-sampled and transferred into an isolation culture chamber of a design similar to the device described by Jannasch et al., (1982) or a chemostat for further processing and bioassays. WHOI (Woods Hole Oceanographic Institute) developed a stand-alone sediment core sampling device (Sheryll, 2009) also designed to be interfaced with existing high-pressure tools for isolation of pure 
cultures of microorganisms in the absence of decompression (Jannasch et al., 1982; Taylor \& Jannasch, 1984; Taylor, 1978; Jannasch \& Wirsen, 1977; Wirsen \& Molyneaux, 1999). The more recently developed lander DOBS (Deep Ocean Benthic Sampler) is able to obtain core sediment samples from the deep ocean without microbial contamination and under in-situ pressure and temperature conditions until retrieval by the ship. Another system called the MAC-EXP system was designed by Jackson et al. (2017) for the retrieval and incubation of benthic sediments under in-situ pressure and temperature conditions and in controlled or manipulated environmental conditions. This system is able to sample down to $3500 \mathrm{~m}$ and to incubate sediments on-board without decompression. Moreover, during incubation, the core chambers can be connected to a laboratory incubation system in order to control enrichment culture, but also oxygen and temperature. The MAC-EXP was successfully used to make a laboratory bioassay related to the effect of pressure and temperature on deep-sea hydrocarbonoclastic microbial communities in artificially oil-polluted subarctic sediments (Perez Calderon et al., 2018).

\section{- In situ incubation with a local consortium}

This second approach consists in directly using local abiotic specificities to perform incubation or enrichment using a local microbial population. An underwater vehicle can be used for a short-term experiment of up to $24 \mathrm{~h}$ (Cahet et al., 1990). A cheaper, safer and more convenient possibility is the use of specific deep-sea landers. According to Tengberg et al. (1995): "Lander is a general term for any autonomous, unmanned oceanographic research vehicle that free-falls to the sea-floor unattached to any cable, and then operates independently on the sea-floor". Once the experiment is over, the lander float backs to the surface for recovery by a ship. Experiments can be conducted from a few days up to 1 year (Kanzog \& Ramette, 2009). Using deep-sea benthic chambers, this kind of device can work under in-situ deep-sea conditions for the study of microbial response to enrichment with various sources of organic carbon (Witte et al., 2003; Bürhing et al., 2006). After the MBO, bioassays with oil enrichment were performed in Gulf of Mexico sediment at $1226 \mathrm{~m}$ depth (Orcutt et al., 2017). This 5-month experiment, using the MIcrobial Methane Observatory for Seafloor Analysis (MIMOSA) lander, was the first to describe the response of deep-sea microbiota to oil release with such a degree of accuracy in terms of the relevance of abiotic factors. Their results clearly pointed out strong differences in comparison with ex-situ experiments (e.g. impact on microbial metabolism and composition). Despite their relative simplicity, landers can be quite efficient and sophisticated. The MIMOSA lander and the "Autonomous Sediment Sampler and Injection Ultra-Lander System" are good examples. The latter 
device, developed by a team of international deep-sea scientists and engineers led by R. Glud (University of Southern Denmark), enables the collection of in situ hadal sediment cores using separate motors to drive four core liners with core catchers into the sediment, where they can perform incubations or fixation of samples at the seafloor (Coley K., 2015). Due to their in situ location, landers also present technical limits including the reduced spectrum of analytical possibilities compared with lab experiments, the obligatory simplest experimental matrix as well as the difficulty to perform time course experiments.

\section{- Cultivation of pure piezotolerant strains}

Cultivation of axenic microbial strains is a convenient, versatile and reproducible way to deepen ecophysiological mechanisms at play during a bioassay (e.g. detailed metabolism of pollutants, gene expression). Cultivation of axenic strictly piezophilic microorganisms is still very challenging even for routine maintenance. Deep-sea piezotolerant strains appear to be a better compromise for pressurized bioassays. Piezotolerant strains can be routinely cultivated under atmospheric pressure before being progressively acclimated to deep-sea hydrostatic pressure for bioassays. Anaerobic bioassays up to 100 bars are relatively easy to process with a simple stainless-steel chamber and HPLC pump to generate the pressure. Using such a system, Scoma et al. (2016) demonstrated that piezosensitive hydrocarbonoclastic bacterial strains presented lower oil biodegradation capacities under pressure. Preprocessing of culture manipulations for pressurized bioassays beyond 100 bars could be performed in a specific anaerobic chamber with a controlled atmosphere when anaerobic culture conditions are required. In general, two types of pressure equipment are available (Marteinsson et al., 1997). One consists in a manual pump and several independent reactors to be used at room or cold temperature. These are routinely used for preservation of deep-sea samples collected under presumed in-situ pressure. A pressure vessel is also used for incubating enrichment cultures and monitoring microbial growth. In the laboratory, the second system is composed of several reactors associated with tubular ovens connected to a pump, a hydraulic accumulator, and an electronic control device. Each reactor can be used at selected temperatures and pressures independently of the others. Experiments can be carried out at up to 600 bars and $300^{\circ} \mathrm{C}$. Microbial cultures are not directly performed in reactors. Instead, incubation of pure cultures and sediment slurry enrichments at elevated pressures is conducted in serum vials or glass and/or plastic syringes completely filled with media and placed in the reactor, which is then fully filled with water and sealed with a lid secured. The gas atmosphere in the syringes and vials is completely removed. The vessel is pressurized using a gas-powered pump or gas tank and 
the pressure is transferred to the samples via the flexible butyl rubber stopper or the piston of the syringe (Figure 3).

Another anaerobic or microaerobic system commonly used for bioassays substitutes the pump with a screw-piston mechanism to generate the pressure and a steel ball or a magnetic stirring bar to mix the medium at up to 400 bars for the more efficient systems (Schedler, 2016). This kind of device allows subsampling during incubation directly from the reactor or glass vial depending on the effective volume thanks to specific valves (Figure 4). The loss of pressure is compensated by screwing the piston. Screwpiston reactors can be autoclaved with medium after residual oxygen is replaced with nitrogen to avoid the emergence of reactive oxygen species at high oxygen partial pressure (Bean, 1945; Cabiscol et al., 2000). In the case of microaerobic cultivation, the amount of oxygen cannot be adjusted in the time and gradually decreases during the bioassay.

Screw-piston reactors were successfully used to demonstrate that pressure cannot be discounted to estimate the biodegradation rate of aromatic hydrocarbons after the MBO. A bioassay was carried out with 2 model hydrocarbonoclastic microbial strains in presence of $n$-hexadecane and naphthalene and showed that some metabolic pathways were more impacted by pressure than previously estimated (Schedler et al., 2014). Finally, a Particle Sinking Simulator (PASS) was developed by Tamburini and colleagues (Tamburini et al., 2009). This promising device can be used to study the behavior of the microbiota inhabiting sinking particles (herein, fecal pellets) in a simulated sink by progressively increasing the hydrostatic pressure in a rotating incubator at up to $40 \mathrm{MPa}$ under controlled temperature (but not $\mathrm{O}_{2}$ partial pressure). It would be interesting to test this device with a piezotolerant strain and simulated MOSSFA (Ramseur, 2010; Passow et al., 2012; Nguyen et al., 2018; Brooks et al., 2015).

In spite of all these interesting prototypes, a technological gap has still to be bridged to develop an efficient, cost-effective and convenient high-pressure laboratory tool and method. The 3 strategies reviewed above all present different interests and disadvantages from a practical view which are summarized in the table 2 . These highlighted criteria should pave the way to the conception of the next generation approach. Amongst all these criteria a clear trend emerges. The ideal next generation process should be ideally able to avoid decompression during transfer of subsamples as well subsequent incubation of piezophilic or piezotolerant microbes in switchable aerobic/anaerobic 
controlled conditions over a long period of time (several months). Alternatively, a proper bioprospection of piezotolerant bacterial strains whose the deep sea origin is well assessed (e.g. piezotolerance and psychrophily of strains isolated with an axenic device from deep sea sediment) could serve to build a reference biocollection for simplified microbiological bioassays (Strategy 3.). These types of approach are necessary to properly evaluate the environmental impact of deep-sea pollution such as drilling waste depositions.

\section{- Conclusion and Prospects}

In the upcoming decades, the worldwide increase in demand for resources will put the deepsea under pressure (Dussauze et al., 2018). The oil \& gas industry is no exception to this trend. Despite the absence of unified, global legislation, local regulations tend to harmonize and be more and more restrictive on the Exploration and Production conditions of offshore exploitation. Oil \& gas industry stakeholders will have to adapt to these changes to maintain their competitiveness. The fact that reported impacts are generally site-specific points out the need for a systematic risk assessment study coupled with in situ measurements as well numerical simulation for each new drilling area. It is highly expectable that a global consensus will emerge in this direction. To date, while the numerical tools and in situ exploration/monitoring tools (e.g. ROV, landers) present a high degree of operability, a functional, versatile and cost-effective tool, and associated protocol, must be developed for high pressure bioassays. Ideally, this technological solution would be switchable between microbiological and animal assay, anoxic and oxic conditions and suitable with a broad spectrum of abiotic factors $\left(\mathrm{T}^{\circ}, \mathrm{pH}, \mathrm{PaO}_{2}\right)$. It should be designed to be simple, exploiting existing proven technological subsolutions and needs to be suitable for on-board experiments in terms of robustness and dimensions. Such a tool could easily become the reference for high pressure bioassays.

\section{Declaration of interest statement}

All the authors wish to confirm that there are no known conflicts of interest associated with this publication and there has been no significant financial support for this work that could have 
influenced its outcome.

\section{References}

Alain, K., Alawi, M., Amend, J., Biddle, J., Borgomano, J., Cockell, C., ... \& Ito, M. 2014. Microbial Life of the Deep Biosphere (Vol. 1). Walter de Gruyter.

Allers, E., Abed, R.M.M., Wehrmann, L.M., Wang, T., Larsson, A.I., Purser, A., de Beer, D. 2013. Resistance of Lophelia pertusa to coverage by sediment and petroleum drill cuttings. Marine Pollution Bulletin, 74, 132-140.

Althaus, F., Williams, A., Schlacher, T.A., Kloser, R.J., Green, M.A., Barker, B.A., Bax, N.J., Brodie, P., Schlacher-Hoenlinger, M.A. 2009. Impacts of bottom trawling on deep-water ecosystems of seamounts are long-lasting. Marine Ecology progress series, 379, 279-294.

Ambec, S., Cohen, M. A., Elgie, S., Lanoie, P. 2013. The Porter hypothesis at 20: can environmental regulation enhance innovation and competitiveness? Review of environmental economics and policy, $7(1), 2-22$.

Arnosti, C., Ziervogel, K., Yang, T., Teske, A. 2016. Oil-derived marine aggregates-hot spots of polysaccharide degradation by specialized bacterial communities. Deep Sea Research Part II: Topical Studies in Oceanography, 129, 179-186.

Auguste, M., Mestre, N.C., Rocha, T.L., Cardoso, C., Cueff-Gauchard, V., Le Bloa, S., CambonBonavita, M.A., Shillito, B., Zbinden, M., Ravaux, J., Bebianno, M.J. 2016. Development of an ecotoxicological protocol for the deep-sea fauna using the hydrothermal vent shrimp Rimicaris exoculata. Aquatic Toxicology, 175, 277-285.

Azwell, T., Blum, M. J., Hare, A., Joye, S., Kubendran, S., Laleian, A., ... \& White, L. E. (2011). The Macondo blowout environmental report. Deepwater Horizon Study Group Environmental Report. 
Bakke, T., Klungsøyr, J., Sanni, S. 2013. Environmental impacts of produced water and drilling waste discharges from the Norwegian offshore petroleum industry. Marine Environmental Research, 92, 154169.

Baussant, T., Nilsen, M., Ravagnan, E., Westerlund, S., Ramanand, S. 2017. Effects of suspended drill cuttings on the coral Lophelia pertusa using pulsed and continuous scenarios. Journal of Toxicology and Environmental Health, Part A., 80(5), 361-382.

Bean, J. W. (1945). Effects of oxygen at increased pressure. Physiological Reviews, 25(1), 1-147.

Bianchi, A., Garcin, J., Tholosan, O. 1999. A high-pressure serial sampler to measure microbial activity in the deep sea. Deep Sea Research Part I: Oceanographic Research Papers, 46(12), 21292142.

Breuer, E., Stevenson, A. G., Howe, J. A., Carroll, J., Shimmield, G. B. 2004. Drill cutting accumulations in the Northern and Central North Sea: a review of environmental interactions and chemical fate. Marine Pollution Bulletin, 48(1-2), 12-25.

Brooks, G. R., Larson, R. A., Schwing, P. T., Romero, I., Moore, C., Reichart, G. J., ... \& Marks, K. P. (2015). Sedimentation pulse in the NE Gulf of Mexico following the 2010 DWH blowout. PLoS One, 10(7), e0132341.

Boschen, R.E., Rowden, A.A., Clark, M.R., Gardner J.P.A. 2013. Mining of deep-sea seafloor massive sulfides: a review of the deposits, their benthic communities, impacts from mining, regulatory frameworks and management strategies. Ocean Coast. Manag., 84, 54-67.

Bühring, S. I., Lampadariou, N., Moodley, L., Tselepides, A., Witte, U. 2006. Benthic microbial and whole-community responses to different amounts of 13C-enriched algae: In situ experiments in the deep Cretan Sea (Eastern Mediterranean). Limnology and Oceanography, 51(1), 157-165.

Cabiscol Català, E., Tamarit Sumalla, J., Ros Salvador, J. 2000. Oxidative stress in bacteria and protein damage by reactive oxygen species. International Microbiology, vol. 3, num. 1, 3-8. 
Cahet, G., Daumas, R., Sibuet, M. 1990. In situ experimentation at the water/sediment interface in the deep sea: 2. Biotransformation of dissolved organic substrates by microbial communities at $2000 \mathrm{~m}$ depth in the Bay of Biscay. Progress in oceanography, 24(1-4), 169-178.

Camus, L., Gullisken, B. 2005. Antioxidant defense properties of Arctic amphipods: comparison between deep-, sublittoral and surface-water species. Marine Biology, 146, 355-362.

Certes, A. 1884a. Note relative à l'action des hautes pressions sur la vitalité des microorganismes d'eau douce et d'eau de mer. C. res. Seanc. Soc. Biol., 36, 220.

Certes A (1884b). Sur la culture, à l'abri des germes atmosphèriques, des eaux et des sédiments rapportés par les expéditions du Travailleur et du Talisman. Comptes Rendus Académie Science 98: 690-693.

Cochrane, S.K.J., Ekehaugb, S., Pettersena, R., Refita, E.C., Hansenb, I.M., Aasb, L.M.S. 2019. Detection of deposited drill cuttings on the sea floor -A comparison between underwater hyperspectral imagery and the human eye. Marine Pollution Bulletin, 145: 67-80

Coley K. 2015. http://maritimeglobalnews.com/news/extreme-sampling-hadal-trenches-bwkjkf

Cordes, E. E., Becker, E. L., Hourdez, S., Fisher, C. R. 2010. Influence of foundation species, depth, and location on diversity and community composition at Gulf of Mexico lower-slope cold seeps. Deep Sea Research Part II: Topical Studies in Oceanography, 57(21-23), 1870-1881.

Daan, R., Boou, K., Mulder, M., Van Weerlee, E.M. 1996. Environmental effects of a discharge of drill cuttings contaminated with ester-based drilling muds in the North Sea. Environmental Toxicology and Chemistry, 15:1709-1722.

Daly, K. L., Passow, U., Chanton, J., Hollander, D. 2016. Assessing the impacts of oil-associated marine snow formation and sedimentation during and after the Deepwater Horizon oil spill. Anthropocene, 13, 18-33.

Davies, J.M., Addy J.M., Blackman, R.A. A., Blanchard, J.R., Ferbrache, J.E., Moore, D.C., Somerville, H.J., Whitehead, A., Wilkinson, T. 1984. Environmental effects of the use of oil-based drilling muds in the North Sea. Marine Pollution Bulletin, 15, 363-370. 
Domingues, G.A.J. 2015. Hydrostatic pressure on cadmium toxicity in Palaemon varians. Dissertaçoes de mestrado em Ecologia Aplicada. Universidade de Aveiro.

Durand A. 2014. L'exploration et l'exploitation des hydrocarbures en mer et la protection de l'environnement. PhD thesis

Dussauze, M., Pichavant-Rafini, K., Belhomme, M., Buzzacott, P., Privat, K., Le Floch, S., Lemaire, P., Theron, M. 2017. Dispersed oil decreases the ability of a model fish (Dicentrarchus labrax) to cope with hydrostatic pressure. Environmental Science and Pollution Research, 24, 3054-3062.

Dussauze, M., Pichavant-Rafini, K., Le Floch, S., Marziou, A., Lemaire, P., Fronteau, L., Belhomme, M., Theron, M. 2016. In vitro Diving Simulation: A New Approach to Assess Biological Impact of Hydrocarbons at Depth. Proceedings of the 39th AMOP Technical Seminar, Ottawa, ON, Canada, 304316

Dussauze, M., Le Floch, S., \& Lelchat, F. (2018). Extreme Environments: The New Exploration/Production Oil Area Problem. In Oil Spill Studies (pp. 83-121). Elsevier.

Edgcomb, V. P., Taylor, C., Pachiadaki, M. G., Honjo, S., Engstrom, I., Yakimov, M. 2016. Comparison of Niskin vs. in situ approaches for analysis of gene expression in deep Mediterranean Sea water samples. Deep Sea Research Part II: Topical Studies in Oceanography, 129, 213-222.

Ekins, P., Vanner, R., Firebrace, J. 2007. Zero emissions of oil in water from offshore oil and gas installations: economic and environmental implications. Journal of Cleaner Production, 15(13-14), $1302-1315$.

Ellis, J. I., Fraser, G., Russell, J. 2012. Discharged drilling waste from oil and gas platforms and its effects on benthic communities. Marine Ecology Progress Series, 456, 285-302.

Fidler, C., Noble, B. 2012. Advancing strategic environmental assessment in the offshore oil and gas sector: Lessons from Norway, Canada, and the United Kingdom. Environmental Impact Assessment Review, 34, 12-21

Fischetti, M. 2015. Deep-Sea Sampler. Scientific American, 313(5), 26-26. 
Fisher, C. R., Demopoulos, A. W., Cordes, E. E., Baums, I. B., White, H. K., Bourque, J. R. 2014. Coral communities as indicators of ecosystem-level impacts of the Deepwater Horizon spill.

Bioscience, 64(9), 796-807

Francis, C. A., Roberts, K. J., Beman, J. M., Santoro, A. E., Oakley, B. B. 2005. Ubiquity and diversity of ammonia-oxidizing archaea in water columns and sediments of the ocean. Proceedings of the National Academy of Sciences, 102(41), 14683-14688

Fraser, G. S., Ellis, J., Hussain, L. 2008. An international comparison of governmental disclosure of hydrocarbon spills from offshore oil and gas installations. Marine Pollution Bulletin, 56(1), 9-13.

Freiwald, A. 2002. Reef-forming cold-water corals. In Wefer, G., Billet, D., Hebbeln, D., Joergensen, B.B., Schlüter, M., Van Weering, T. (Eds.), Ocean Margin Systems. Springer Verlag, Berlin Heidelberg, 365-385.

Godø, O. R., Klungsøyr, J., Meier, S., Tenningen, E., Purser, A., \& Thomsen, L. (2014). Real time observation system for monitoring environmental impact on marine ecosystems from oil drilling operations. Marine pollution bulletin, 84(1-2), 236-250.

Gray, J.S., Clarke, K.R., Warwick, R.M., Hobbs, G. 1990. Detection of initial effects of pollution on marine benthos: an example from the Ekofisk and Eldfisk oil fields, North Sea. Marine Ecology Progress Series, 66, 285-299.

Gundersen, K., Mountain, C. W. 1973. Oxygen utilization and pH change in the ocean resulting from biological nitrate formation. In Deep Sea Research and Oceanographic Abstracts, Vol. 20, No. 12, 1083-1091

Hastings, D. W., Schwing, P. T., Brooks, G. R., Larson, R. A., Morford, J. L., Roeder, T., Quinn, K.A., Bartlett, T., Romero, I.C., Hollander, D. J. 2016. Changes in sediment redox conditions following the BP DWH blowout event. Deep Sea Research Part II: Topical Studies in Oceanography, 129, 167-178.

Head, I. M., Jones, D. M., Röling, W. F. 2006. Marine microorganisms make a meal of oil. Nature Reviews Microbiology, 4(3), 173. 
Heeschen, K. U., Hohnberg, H. J., Haeckel, M., Abegg, F., Drews, M., Bohrmann, G. 2007. In situ hydrocarbon concentrations from pressurized cores in surface sediments, Northern Gulf of Mexico. Marine Chemistry, 107(4), 498-515.

Hsing, P.-Y., Fu, B., Larcom, E.A., Berlet, S.P., Shank, T.M., Govindarajan, A.F., Lukasiewicz, A.J., Dixon, P.M., Fisher, C.R. 2013. Evidence of lasting impact of the Deepwater Horizon oil spill on a deep Gulf of Mexico coral community. Elementa: Science of the Anthropocene. http://dx.doi.org/10.12952/journal. elementa.000012.

Hurley, G., Ellis, J.I. 2004. Environmental effects of ex plo-ratory drilling offshore Canada: environmental effects monitoring data and literature review. Prepared for the Canadian Environmental Assessment Agency Regulatory Advisory Committee, Ottawa, Ontario.

IOGP report. 2003. Environmental aspects of the use and disposal of non aqueous drilling fluids associated with offshore oil \& gas operations. IOGP Report No. 342.

IOGP report. 2016. Environmental fates and effects of ocean discharge of drill cuttings and associated drilling fluids from offshore oil and gas operations (https://www.iogp.org/bookstore/product/environmental-fate-and-effects-of-ocean-discharge-of-drillcuttings-and-associated-drilling-fluids-from-offshore-oil-and-gas-operations/)

Ismail A.R., Alias A.H., Sulaiman W.R.W., Jaafar M.Z., Ismail I. 2017. Drilling Fluid Waste Management in Drilling for Oil and Gas Wells. Chemical Engineering Transactions. 56. 1351-1356.

Jackson, K., Witte, U., Chalmers, S., Anders, E., Parkes, J. 2017. A system for retrieval and incubation of benthic sediment cores at in situ ambient pressure and under controlled or manipulated environmental conditions. Journal of atmospheric and oceanic technology, 34(5), 983-1000.

Jannasch, H. W., Taylor, C. D. 1984. Deep-sea microbiology. Annual review of microbiology, 38(1), 487-487.

Jannasch, H. W., Wirsen, C. O. 1973. Deep-sea microorganisms: in situ response to nutrient enrichment. Science, 180(4086), 641-643.

Jannasch, H. W., Wirsen, C. O. 1977. Retrieval of concentrated and undecompressed microbial populations from the deep sea. Applied and environmental Microbiology, 33(3), 642-646. 
Jannasch, H. W., Wirsen, C. O., Winget, C. L. 1973. A bacteriological pressure-retaining deep-sea sampler and culture vessel. In Deep Sea Research and Oceanographic Abstracts, Vol. 20, No. 7, 661664

Järnegren, J., Brooke, S., Jensen, H. 2017. Effects of drill cuttings on larvae of the cold-water coral Lophelia pertusa. Deep Sea Research Part II; Topical Studies in Oceaography, 137, 454-462. doi:10.1016/j.dsr2.2016.06.014.

Johnson, F. H., \& Eyring, H. (1970). The kinetic basis of pressure effects in biology and chemistry. High pressure effects on cellular processes, 1, 44. Acad. Press New York pp1-44.

Johnson F.H., Eyring H. Stovel B. 1974. The theory of rate processes in biology and medicine. Wiley, New York.

Jorissen, F.J., Bicchi, E., Duchemin, G., Durrieu, J., Galgani, F., Cazes, L., Gaultier, M., Camps, R. 2009. Impact of oil-based drill mud disposal on benthic foraminiferal assemblages on the continental margin off Angola. Deep Sea Research Part II, 56, 2270-2291.

Joye, S. B., Teske, A. P., Kostka, J. E. 2014. Microbial dynamics following the Macondo oil well blowout across Gulf of Mexico environments. BioScience, 64(9), 766-777.

Kanzog, C., Ramette, A. 2009. Microbial colonisation of artificial and deep-sea sediments in the Arctic Ocean. Marine Ecology, 30(4), 391-404.

Kato, C. 2006. 31 Handling of Piezophilic Microorganisms. Methods in microbiology, Vol. 35, 733-741

Kimes, N. E., Callaghan, A. V., Aktas, D. F., Smith, W. L., Sunner, J., Golding, B. T., Drozdowska M, Hazen TC, Suflita J.M., Morris, P. J. 2013. Metagenomic analysis and metabolite profiling of deep-sea sediments from the Gulf of Mexico following the Deepwater Horizon oil spill. Frontiers in Microbiology, $4,50$.

King, G. M., Kostka, J. E., Hazen, T. C., Sobecky, P. A. 2015. Microbial responses to the Deepwater Horizon oil spill: from coastal wetlands to the deep sea. Annual review of marine science, 7, 377-401. 
Kingston, P. F. 1992. Impact of offshore oil production installations on the benthos of the North Sea. ICES Journal of Marine Science, 49(1), 45-53.

Knol, M. 2011. The uncertainties of precaution: Zero discharges in the Barents Sea. Marine Policy, 35(3), 399-404.

Kopecka-Pilarczyk, J., Coimbra, J. 2010a. The effect of elevated hydrostatic pressure upon selected biomarkers in juvenile blackspot seabream Pagellus bogaraveo in a 14 day-long experiment. Journal of Fish Biology, 77, 279-284.

Kopecka-Pilarczyk, J., Coimbra, J. 2010b. Short term high hydrostatic pressure effect on selected biomarkers in silver eel (Anguilla anguilla). Journal of Experimental Marine Biology and Ecology, 391, $118-124$.

Kornblatt J.A., Kornblatt M.J. 2002. The effects of osmotic and hydrostatic pressures on macromolecular systems. Biochimica et Biophysica Acta (BBA) - Protein Structure and Molecular Enzymology, Volume 1595, Issues 1-2, 25, 30-47.

Kostka, J. E., Prakash, O., Overholt, W. A., Green, S., Freyer, G., Canion, A., Delgardio, J., Norton, N., Hazen, T.C., Huettel, M. 2011. Hydrocarbon-degrading bacteria and the bacterial community response in Gulf of Mexico beach sands impacted by the Deepwater Horizon oil spill. Applied and environmental microbiology, 77(22):7962-74, AEM-05402.

Kunugi S. 1992. Enzyme reactions under high pressure and their applications. Annals of the New York Academy of Sciences, 672: 293-304.

Larsson, A.I., Purser, A. 2011. Sedimentation on the cold-water coral Lophelia pertusa: cleaning efficiency from natural sediments and drill cuttings. Marine Pollution Bulletin, 62: 1159-1168.

Lemaire, B. 2017. Hydrostatic pressure and the experimental toxicology of marine fishes: The elephant in the room. Marine Pollution Bulletin, 124(1), 206-210 
Lemaire, B., Debier, C., Calderon, P.B., Thome, J.P., Stegeman, J., Mork, J., Rees, J.F. 2012. Precisioncut liver slices to investigate responsiveness of deep-sea fish to contaminants at high pressure. Environmental Science Technology, 46, 10310-10316.

Lemaire, B., Mignolet, E., Debier, C., Calderon, P.B., Thome, J.P., Rees, J.F. 2016. High hydrostatic pressure influences the in vitro response to xenobiotics in Dicentrarchus labrax liver. Aquatic Toxicology, 173, 43-52.

Lepland, A., Mortensen, P.B., 2008. Barite and barium in sediments and coral skeletons around the hydrocarbon exploration drilling site in the Traena Deep, Norwegian Sea. Environ. Geol. 56, 119-129.

Macdonald, A. G. (1984). The effects of pressure on the molecular structure and physiological functions of cell membranes. Philosophical Transactions of the Royal Society of London. B, Biological Sciences, 304(1118), 47-68.

Maddahi, M., Mortazavi, S. J. 2011. A Review on Offshore Concepts and Feasibility Study Considerations. In SPE Asia Pacific Oil and Gas Conference and Exhibition. Society of Petroleum Engineers.

Main, C. E., Ruhl, H. A., Jones, D. O. B., Yool, A., Thornton, B., Mayor, D. J. 2015. Hydrocarbon contamination affects deep-sea benthic oxygen uptake and microbial community composition. Deep Sea Research Part I: Oceanographic Research Papers, 100, 79-87.

Malachosky, E., Shannon, B. E., Jackson, J. E., Aubert, W. G. 1993. Offshore disposal of oil-based drilling-fluid waste: an environmentally acceptable solution. SPE drilling \& completion, 8(04), 283-287. Mangelsdorf, K., Zink, K. G., Birrien, J. L., Toffin, L. 2005. A quantitative assessment of pressure dependent adaptive changes in the membrane lipids of a piezosensitive deep sub-seafloor bacterium. Organic Geochemistry, 36(11), 1459-1479.

Marietou, A., Chastain, R., Scoma, A., Hazen, T. C., \& Bartlett, D. H. 2018. The effect of hydrostatic pressure on enrichments of hydrocarbon degrading microbes from the Gulf of Mexico following the Deepwater Horizon oil spill. Frontiers in microbiology, 9, 808. 
Marteinsson VT, Moulin P, Birrien JL, Gambacorta A, Vernet M, Prieur D. 1997. Physiological responses to stress conditions and barophilic behavior of the hyperthermophilic vent archaeon Pyrococcus abyssi. Applied and Environmental Microbiology, 63: 1230-1236.

Mason, O. U., Hazen, T. C., Borglin, S., Chain, P. S., Dubinsky, E. A., Fortney, J. L., Han, J., Holman, H.Y., Hultman, .J, Lamendella, R., Mackelprang, R., Malfatti, S., Tom, L.M., Tringe, S.G., Woyke, T., Zhou, J., Rubin, E.M., Jansson, J.K. 2012. Metagenome, metatranscriptome and single-cell sequencing reveal microbial response to Deepwater Horizon oil spill. The ISME journal, 6(9), 1715-27.

Mason, O. U., Scott, N. M., Gonzalez, A., Robbins-Pianka, A., Bælum, J., Kimbrel, J., Bouskill N.J., Prestat, E., Borglin, S, Joyner, D.C., Fortney, J.L., Jurelevicius, D., Stringfellow, W.T., Alvarez-Cohen, L., Hazen, T.C. 2014. Metagenomics reveals sediment microbial community response to Deepwater Horizon oil spill. The ISME journal, 8(7), 1464.

McConville, M. M., Roberts, J. P., Boulais, M., Woodall, B., Butler, J. D., Redman, A. D., Parkerton T.F., Arnold W.R., Guyomarch J., Le Floch S., Bytingsvik J., Camus L., Volety A., Brander, S. M. 2018. The sensitivity of a deep-sea fish species (Anoplopoma fimbria) to oil-associated aromatic compounds, dispersant, and Alaskan North Slope crude oil. Environmental Toxicology and Chemistry, 37(8), 22102221

Menzie, C. A. 1982. The environmental implications of offshore oil and gas activities. Environmental Science \& Technology, 16(8), 454A-472A.

Merrie, A., Dunn, D. C., Metian, M., Boustany, A. M., Takei, Y., Elferink, A. O., Ota, Y., Christensen, V., Halpin, P.N., Österblom, H. 2014. An ocean of surprises-Trends in human use, unexpected dynamics and governance challenges in areas beyond national jurisdiction. Global Environmental Change, 27, 19-31.

Napp, A. P., Pereira, J. E. S., Oliveira, J. S., Silva-Portela, R. C., Agnez-Silva, L. F., Peralba, M. C., Benton, F.M., Passaglia, L.M.P., Thompson, C.E., Vainstein, M. H. 2018. Comparative metagenomics reveals different hydrocarbon degradative abilities from enriched oil-drilling waste. Chemosphere, 209, 7-16 
Netto, S. A., Gallucci, F., \& Fonseca, G. (2009). Deep-sea meiofauna response to synthetic-based drilling mud discharge off SE Brazil. Deep Sea Research Part II: Topical Studies in Oceanography, 56(1-2), 41-49.

Nguyen, T. T., Cochrane, S. K., Landfald, B. 2018. Perturbation of seafloor bacterial community structure by drilling waste discharge. Marine pollution bulletin, 129(2), 615-622.

Nguyen, T. V., Voldsund, M., Elmegaard, B., Ertesvåg, I. S., Kjelstrup, S. 2014. On the definition of exergy efficiencies for petroleum systems: Application to offshore oil and gas processing. Energy, 73, 264-281.

Olsen GH, Coquillé N, Le Floch S, Geraudie P, Dussauze M, Lemaire P, Camus L. 2016. Sensitivity of the deep-sea amphipod Eurythenes gryllus to chemically dispersed oil. Environmental science and Pollution Research (IF:2.757) 23:6497-6505. DOI: 10.1007/s11356-015-5869-5

Olsgard, F., Gray, J.S. 1995. A comprehensive analysis of effects of offshore oil and gas exploration and production on the benthic communities of the Norwegian continental shelf. Marine Ecology Progress Series, 122:277-306.

Orcutt, B. N., Lapham, L. L., Delaney, J., Sarode, N., Marshall, K. S., Whaley-Martin, K. J., Slater, G., Wheat C.G., Girguis, P. R. 2017. Microbial response to oil enrichment in Gulf of Mexico sediment measured using a novel long-term benthic lander system. Elementa Science of the Anthropocene, 5:18.

Parkes, R. J., Sellek, G., Webster, G., Martin, D., Anders, E., Weightman, A. J., Sass, H. 2009. Culturable prokaryotic diversity of deep, gas hydrate sediments: first use of a continuous high-pressure, anaerobic, enrichment and isolation system for subseafloor sediments (DeeplsoBUG). Environmental Microbiology, 11(12), 3140-3153.

Passow, U., Ziervogel, K., Asper, V., Diercks, A. 2012. Marine snow formation in the aftermath of the Deepwater Horizon oil spill in the Gulf of Mexico. Environmental Research Letters, 7(3), 035301.

Perez Calderon, L. J., Gontikaki, E., Potts, L. D., Shaw, S., Gallego, A., Anderson, J. A., Witte, U. 2018. Pressure and temperature effects on deep-sea hydrocarbon-degrading microbial communities in subarctic sediments. MicrobiologyOpen, e768. 
Pilskaln, C.H., Churchill, J.H., Mayer, L.M., 1998. Resuspension of sediment by bottom trawling in the gulf of maine and potential geochemical consequences. Conserv. Biol. 12, 1223-1229.

Pinder, D. 2001. Offshore oil and gas: global resource knowledge and technological change. Ocean \& Coastal Management, 44(9-10), 579-600.

Purser, A., Thomsen, L. 2012. Monitoring strategies for drill cutting discharge in the vicinity of coldwater coral ecosystems. Marine pollution bulletin, 64(11), 2309-2316.

Purser, A .2015. A Time Series Study of Lophelia pertusa and Reef Megafauna Responses to Drill Cuttings Exposure on the Norwegian Margin. PLOS ONE. 10(7): e0134076. https://doi.org/10.1371/journal.pone.0134076

Ramseur, J. L. 2010. Deepwater Horizon oil spill: the fate of the oil. Washington, DC: Congressional Research Service, Library of Congress.

Rana, S. 2010. Environmental Regulations, Technology, and Cost of Compliance for Oil \& Gas Operations. In Trinidad and Tobago Energy Resources Conference. Society of Petroleum Engineers.

Ravaux, J., Hamel, G., Zbinden, M., Tasiemski, A. A., Boutet, I., Léger, N., Tanguy, A., Jollivet, D., Shillito, B. 2013. Thermal limit for metazoan life in question: in vivo heat tolerance of the Pompeii worm. PLoS One, 8(5), https://doi.org/10.1371/journal.pone.0064074

Roberts, J.M., Wheeler, A.J., Freiwald, A. 2006. Reefs of the deep: the biology and geology of coldwater coral ecosystems. Science, 312, 543-547.

Roberts, J.M., Wheeler, A.J., Freiwald, A., Cairns, S.D. 2009. Cold-water Corals: The Biology and Geology of Deep-sea Coral Habitats. Cambridge University Press, Cambridge, p. 334.

Roer, R.D., Sidelyova, V.G., Brauer, R.W., Galazii, G.I. 1984. Effects of pressure on oxygen consumption in cottid fish from lake Baikal. Experientia, 40, 771-773.

Rogers, A.D. 1999. The biology of Lophelia pertusa (Linnaeus 1758) and other deepwater reef-forming corals and impacts from human activities. International Review Hydrobiology, 84, 315-406. 
Roussel, E. G., Bonavita, M. A. C., Querellou, J., Cragg, B. A., Webster, G., Prieur, D., \& Parkes, R. J. 2008. Extending the sub-sea-floor biosphere. Science, 320(5879), 1046-1046.

Schaanning, M., Lichtenthaler, R., \& Rygg, B. 1997. Biodegradation of Esters and Olefins in Drilling Mud Deposited on Arctic soft-bottom communities in a low-temperature Mesocosm. In NIVA-rapport, http://hdl.handle.net/11250/209636

Schedler, M., Hiessl, R., Juárez, A. G. V., Gust, G., \& Müller, R. 2014. Effect of high pressure on hydrocarbon-degrading bacteria. $A M B$ express, 4(1), 77.

Schedler, M. 2016. Microbial degradation of crude oil at high pressure. Doctoral dissertation, Technische Universität Hamburg. 177p

Schultheiss, P. J., Francis, T. J. G., Holland, M., Roberts, J. A., Amann, H., Parkes, R. J., Martin, D., Rothfuss, M., Tyunder, F., Jackson, P. D. 2006. Pressure coring, logging and subsampling with the HYACINTH system. Geological Society, London, Special Publications, 267(1), 151-163

Scoma, A., Barbato, M., Hernandez-Sanabria, E., Mapelli, F., Daffonchio, D., Borin, S., Boon, N. 2016. Microbial oil-degradation under mild hydrostatic pressure (10 MPa): which pathways are impacted in piezosensitive hydrocarbonoclastic bacteria?. Scientific reports, 6, 23526

Sébert P., Theron M., Vetier A. 2004. Pressure and temperature interactions on cellular respiration; e review. Cellular and Molecular Biology, 50(4), 491-500

Sheryll, R. P. (2009). New technology for uncontaminated and pressure controlled deep-sea sampling:" Deep Ocean Benthic Sampler"(DOBS) (Vol. 70, No. 08).

Silva, M., Etnoyer, P. J., MacDonald, I. R. 2016. Coral injuries observed at mesophotic reefs after the Deepwater Horizon oil discharge. Deep Sea Research Part II: Topical Studies in Oceanography, 129, 96-107.

Somero G.N., 1991. Hydrostatic pressure and adaptation to the deep sea. In: Environmental and metabolic animal physiology. Comparative animal Physiology. C Ladd Prosser (Ed.) pp167-204.

Tabor, P. S., Ohwada, K., Colwell, R. R. 1981. Filterable marine bacteria found in the deep sea: distribution, taxonomy, and response to starvation. Microbial ecology, 7(1), 67-83. 
Tamburini, Christian, Goutx M., Guigue C., Garel, M., Lefèvre, D., Charrière, B., Sempéré, R., Pepa, S., Peterson, M.L., Wakeham, S., Lee C. 2009. Effects of hydrostatic pressure on microbial alteration of sinking fecal pellets. Deep Sea Research Part II: Topical Studies in Oceanography, 56(18), 15331546

Taylor, C. D., Doherty, K. W., Molyneaux, S. J., Morrison, A. T., Billings, J. D., Engstrom, I. B., Pfitsch, D.W., Honjo, S. 2006. Autonomous Microbial Sampler (AMS), a device for the uncontaminated collection of multiple microbial samples from submarine hydrothermal vents and other aquatic environments. Deep Sea Research Part I: Oceanographic Research Papers, 53(5), 894-916.

Tengberg, A., De Bovee, F., Hall, P., Berelson, W., Chadwick, D., Ciceri, G., Crassous, P., Devol, A., Emerson, S., gage, J., Glud, R., graziottini, F., Gundersen, J., Hammond, D., Helder, W., Hinga, K., Holby, O., Jahnke, R., Khripounoff, A., Lieberman, S., Nuppenau, V., pfannkuche, O., Reimers, C., Rowe, G., Sahami, A., Sayles, F., Schurter, M., Smallman, D., Wehrli, B., De Wilde, P. 1995. Benthic chamber and profiling landers in oceanography-a review of design, technical solutions and functioning. Progress in Oceanography, 35(3), 253-294.

Theron M., Sébert P. 2003. Hydrostatic pressure and cellular respiration: are the values observed postdecompression representative of the reality under pressure? Mitochondrion 3. 75-81

Trannum, H.C., Nilsson, H.C., Schaanning, M.T., Øxnevad, S., 2010. Effects of sedimentation from water-based drill cuttings and natural sediment on benthic macrofaunal community structure and ecosystem processes. J. Exp. Mar. Biol. Ecol. 383, 111-121.

Trannum, H. C., Nilsson, H. C., Schaanning, M. T., Norling, K. 2011. Biological and biogeochemical effects of organic matter and drilling discharges in two sediment communities. Marine Ecology Progress Series, 442, 23-36.

Veil, J. A. 2002. Drilling waste management: past, present, and future. In SPE annual technical conference and exhibition. Society of Petroleum Engineers.

Vevers, W.F., Dixon, D.R., Dixon, L.R.J. 2010. The role of hydrostatic pressure on developmental stages of Pomatoceros lamarcki (Polychaeta: Serpulidae) exposed to water accomodated fractions of crude oil and positive genotoxins at simulated depths of 1000-3000 m. Environmental Pollution, 158, 1702-1709. 
White, H. K., Hsing, P. Y., Cho, W., Shank, T. M., Cordes, E. E., Quattrini, A. M., ... \& Brooks, J. M. (2012). Impact of the Deepwater Horizon oil spill on a deep-water coral community in the Gulf of Mexico. Proceedings of the National Academy of Sciences, 109(50), 20303-20308.

White, M., Wolff, G.A., Lundälv, T., Guihen, D., Kiriakoulakis, K., Lavaleye, M., Duineveld, G. 2012. Cold-water coral ecosystem (Tisler Reef, Norwegian Shelf) may be a hotspot for carbon cycling. Marine Ecology Progress Series, 465, 11-23.

Wirsen, C. O., \& Molyneaux, S. J. 1999. A study of deep-sea natural microbial populations and barophilic pure cultures using a high-pressure chemostat. Applied and environmental microbiology, 65(12), 5314-5321.

Witte, U., Aberle, N., Sand, M., Wenzhöfer, F. 2003. Rapid response of a deep-sea benthic community to POM enrichment: an in situ experimental study. Marine Ecology Progress Series, 251, 27-36.

Yanagibayashi, M., Nogi, Y., Li, L., Kato, C. 1999. Changes in the microbial community in Japan Trench sediment from a depth of $6292 \mathrm{~m}$ during cultivation without decompression. FEMS microbiology letters, 170(1), 271-279.

Yancey P.H. 2005 Organic osmolytes as compatible, metabolic and counteracting cytoprotectants in high osmolarity and other stresses. The Journal of Experimental Biology 208, 2819-2830 2819 doi:10.1242/jeb.01730

Yayanos, A. A. 1978. Recovery and maintenance of live amphipods at a pressure of 580 bars from an ocean depth of 5700 meters. Science, 200(4345), 1056-1059.

Yayanos, A. A. 1986. Evolutional and ecological implications of the properties of deep-sea barophilic bacteria. Proceedings of the National Academy of Sciences, 83(24), 9542-9546.

Yayanos, A. A., Dietz, A. S., Van Boxtel, R. 1979. Isolation of a deep-sea barophilic bacterium and some of its growth characteristics. Science, 205(4408), 808-810.

Yayanos, A. A., Dietz, A. S., Van Boxtel, R. 1981. Obligately barophilic bacterium from the Mariana Trench. Proceedings of the National Academy of Sciences, 78(8), 5212-5215.

ZoBell, C. E. 1952. Bacterial life at the bottom of the Philippine Trench. Science, 115(2993), 507-508. 


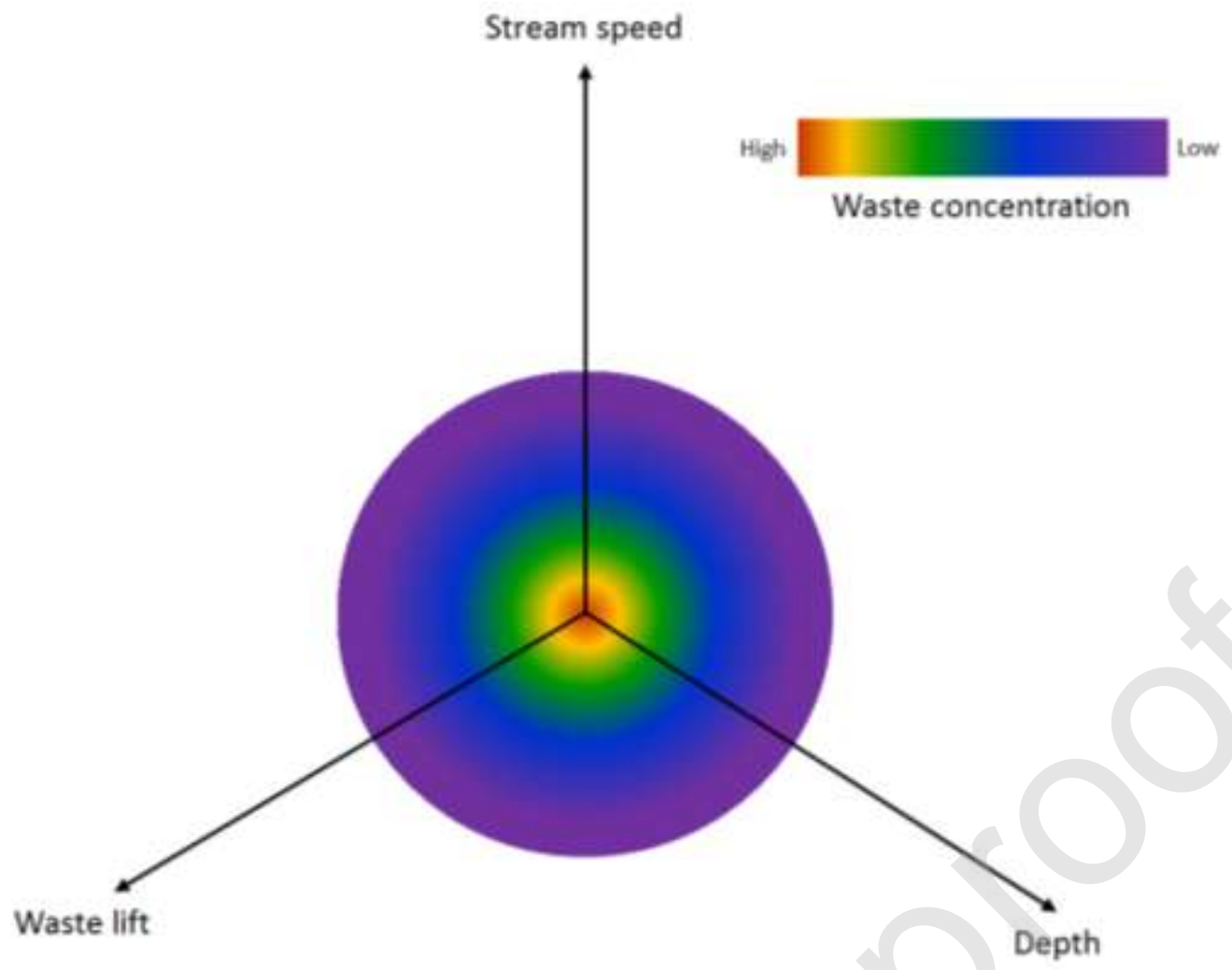

Figure 1: Waste distribution as is a barycenter of waste lift, depth and stream speed as a function of their respective intensities. The concentration of waste is represented by a heatmap from important (hot) to low (purple). 


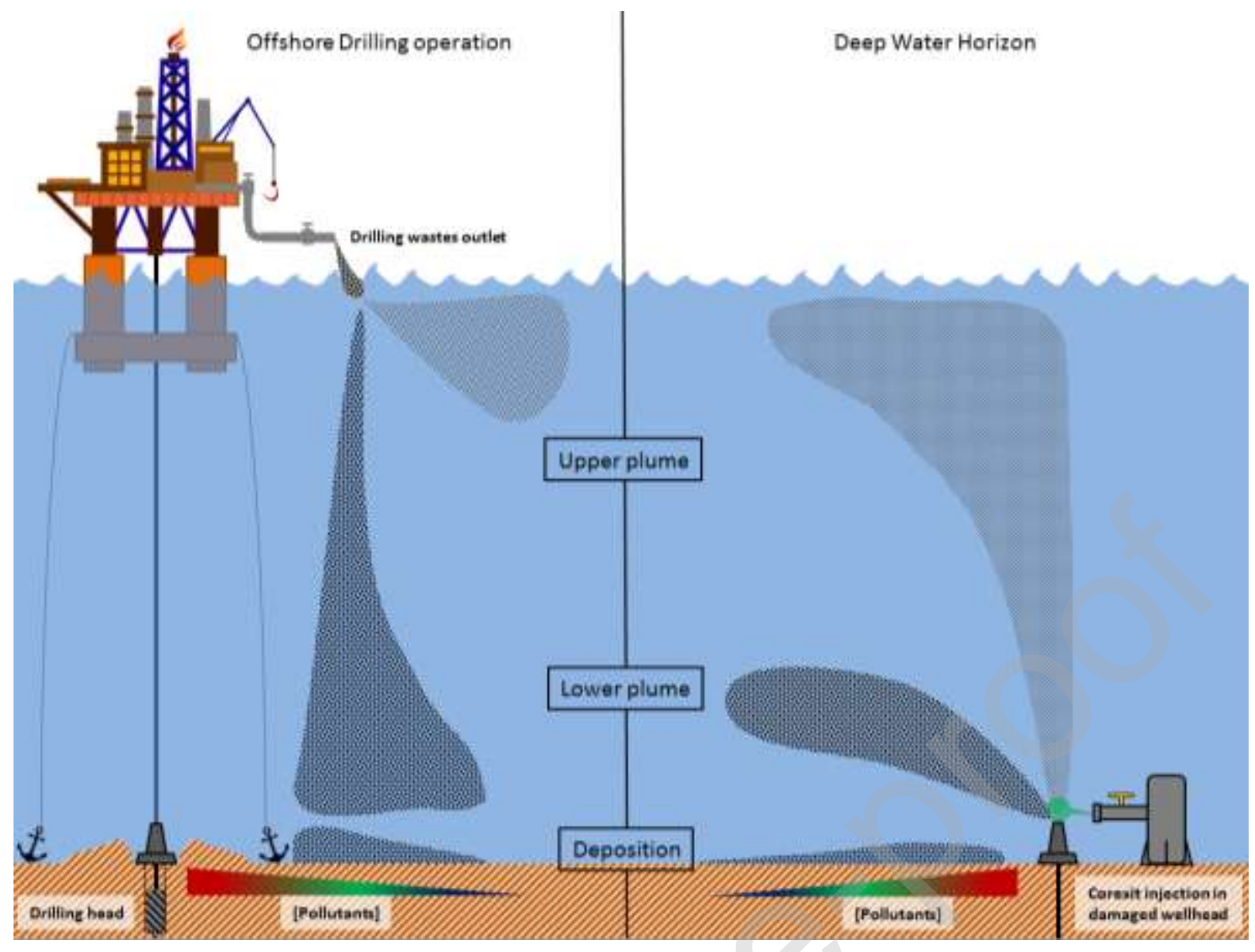

Figure 2: Schematic representation of the similarities between idealized plumes and deposition between deepwater offshore drilling operation and DWH hydrocarbon propagation post blowout. 


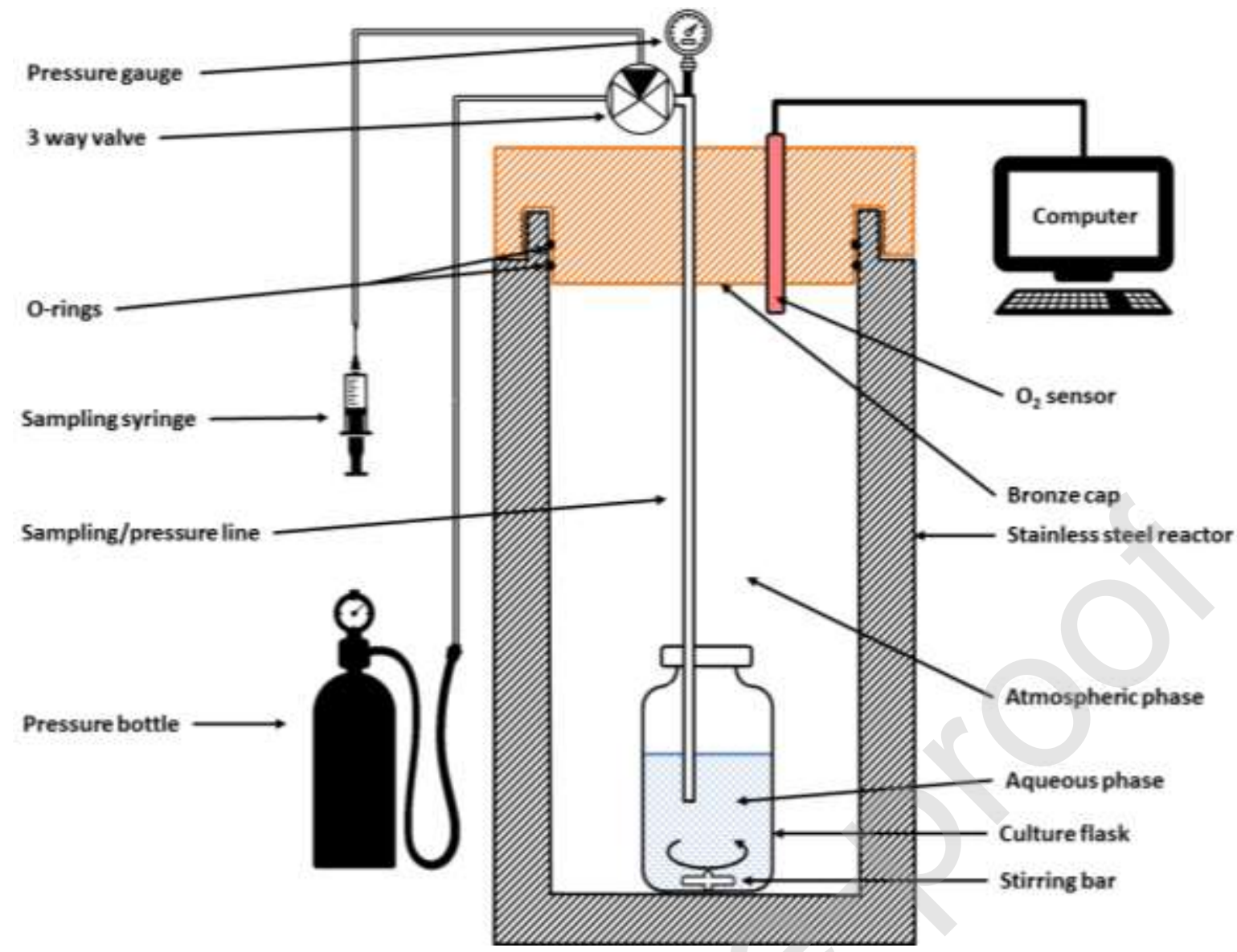

Figure 3: Schematic view of a pressurized reactor (adapted from Schedler, 2016).

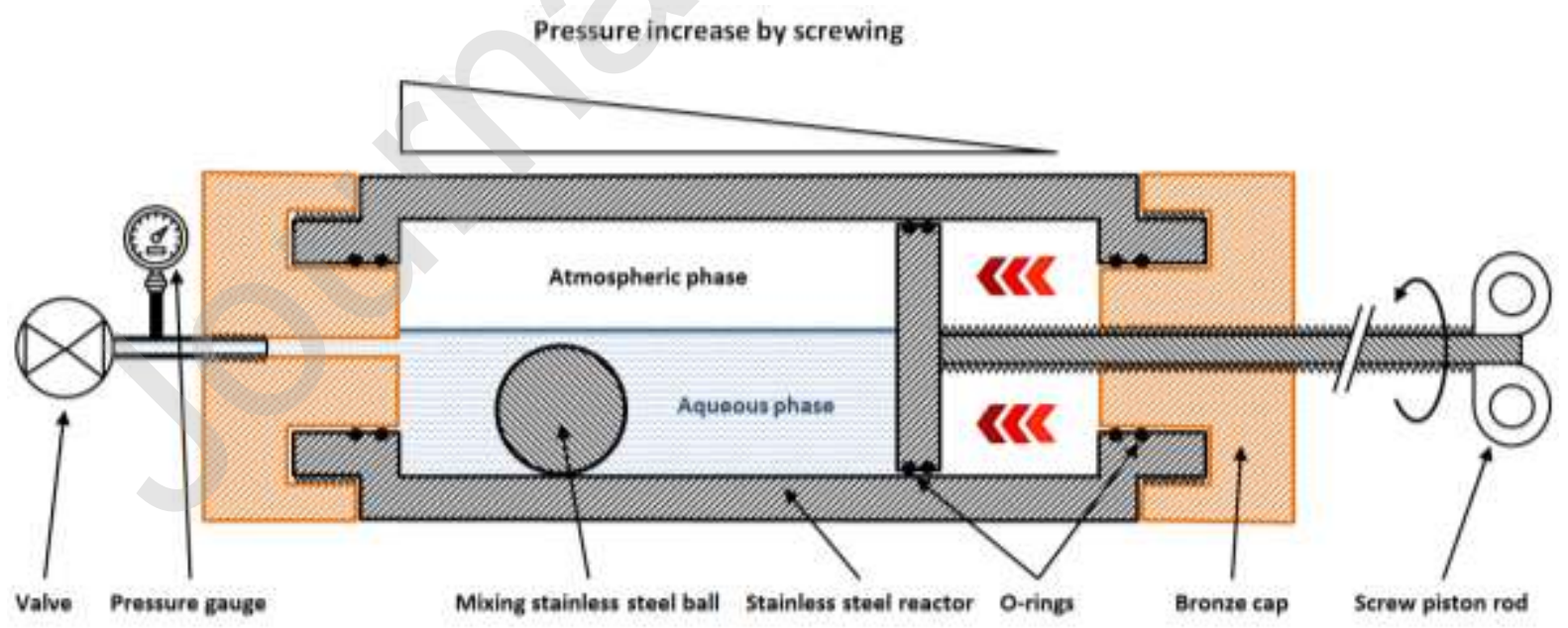

Figure 4: Schematic view of a screw-piston reactor (adapted from Schedler, 2016). 
Table 1: Non exhaustive overview of environmental regulations of offshore disposal of drilling fluids and cuttings.

\begin{tabular}{|c|c|c|c|}
\hline \multicolumn{2}{|r|}{ World area } & Legislative body & Main environmental regulations \\
\hline \multirow[t]{2}{*}{$\begin{array}{l}\text { North } \\
\text { America }\end{array}$} & USA & $\begin{array}{l}\text { United States Environmental Protection Agency (US-EPA) } \\
\text { regulations }\end{array}$ & $\begin{array}{l}\text { Discharges of Oil-based mud (OBM) and } \\
\text { Synthetic-based mud (SBM) are forbidden into US } \\
\text { territorial waters. } \\
\text { Nevertheless, regulatory approaches can be } \\
\text { adapted considering area / industry request / } \\
\text { specificities. }\end{array}$ \\
\hline & Canada & States' and territories' law agreements prevail over federal & $\begin{array}{l}\text { General context, Discharges of Oil-based mud } \\
\text { (OBM) and Synthetic-based mud (SBM) are } \\
\text { forbidden. } \\
\text { Nevertheless, industries like the Canada- } \\
\text { Newfoundland and Labrador Offshore Petroleum } \\
\text { Board can obtain some regulation adaptation. }\end{array}$ \\
\hline $\begin{array}{l}\text { South } \\
\text { America }\end{array}$ & \begin{tabular}{|l|} 
Brazil \\
Venezuela
\end{tabular} & $\begin{array}{l}\text { Regional convention related to environmental control and } \\
\text { regulations which include drilling activities }\end{array}$ & OBM and SBM discharges are prohibited \\
\hline \multirow[t]{3}{*}{$\begin{array}{l}\text { Asia } \\
\text { Pacific }\end{array}$} & Australia & $\begin{array}{l}\text { States' and territories' law agreements prevail over Commonwealth } \\
\text { legislations }\end{array}$ & $\begin{array}{l}\text { General context, Discharges of Oil-based mud } \\
\text { (OBM) and Synthetic-based mud (SBM) are } \\
\text { forbidden. }\end{array}$ \\
\hline & China & $\begin{array}{l}\text { The Ministry of Environmental Protection of the People's republic of } \\
\text { China is in charge of the drilling waste industry regulation }\end{array}$ & Discharges of OBM are forbidden \\
\hline & Thailand & $\begin{array}{l}\text { The ministry of natural resources and environment is in charge of } \\
\text { the drilling waste industry regulation }\end{array}$ & forbidden \\
\hline \multirow[t]{2}{*}{ Europe } & \multirow[t]{2}{*}{$\begin{array}{l}\text { European Union (the } \\
\text { UK, Norway...), } \\
\text { Associated countries } \\
\text { and ultramarine } \\
\text { territories }\end{array}$} & $\begin{array}{l}\text { Different groups are in charge of the regulation depending the } \\
\text { considered area } \\
\text { For the North Sea and the Baltic sea, Helcom (Helsinki } \\
\text { Commission) and OSPAR (Oslo-Paris convention) define the } \\
\text { "precautionary principle" and the "polluter pays principle". OSPAR } \\
\text { Decision } 2000 / 2 \text { on a harmonized mandatory Control System for the } \\
\text { Use and Reduction of the Discharge of Offshore Chemicals (as } \\
\text { amended by OSPAR Decision 2005/1). And OSPAR Decision } \\
2000 / 3 \text { on the Use of organic-Phase Drilling Fluids (OPF) and the } \\
\text { Discharge of OPF-Contaminated Cuttings. } \\
\text { Regulation for the Mediterranean Sea is defined by the Barcelona } \\
\text { Convention and its offshore protocol }\end{array}$ & $\begin{array}{l}\text { The regulation goes for a } 0 \text { discharges. } \\
\text { But a list of authorized substances is implemented } \\
\text { and if their concentrations are below a limit, then } \\
\text { discharges are also authorized. } \\
\text { European Union's Marine Strategy Framework } \\
\text { Directive (MSFD), which states that all the } \\
\text { European seas should attain Good Environmental } \\
\text { Status (GES) by } 2020 \text {. }\end{array}$ \\
\hline & & $\begin{array}{l}\text { For French Guyana, the Guyana decree was implemented in } 2012 \\
\text { by the French government. }\end{array}$ & $\begin{array}{l}\text { French Guyana decree say that the amount of } \\
\text { drilling fluid must be lower than } 5 \% \text { of the total } \\
\text { waste volume }\end{array}$ \\
\hline
\end{tabular}




\begin{tabular}{|l|l|l|}
\hline $\begin{array}{l}\text { Middle } \\
\text { East }\end{array}$ & Persian Gulf & $\begin{array}{l}\text { MEMAC (Marine Emergency Mutual Aid Centre) is a regional } \\
\text { intergovernmental organization concerns with marine pollution } \\
\text { The Kuwait Regional Convention for Co-operation on the Protection } \\
\text { of the Marine Environment from Pollution }\end{array}$ \\
\hline
\end{tabular}

No pollution is allowed

SBM must be treated before being discharged to eliminate all potentially toxic compounds 
Table 2: Technical overview of the principal strategies used for pressurized microbiological bioassays.

\begin{tabular}{|c|c|c|c|c|c|}
\hline \multirow{2}{*}{ Strategy } & \multicolumn{2}{|c|}{ Technical complexity } & \multirow{2}{*}{ Cost } & \multirow{2}{*}{ Application range } & \multirow{2}{*}{ Relevance } \\
\hline & Microbiological constraints & Technical requirement & & & \\
\hline $\begin{array}{l}\text { 1. Ex situ incubation with an } \\
\text { indigenous consortium }\end{array}$ & $\begin{array}{l}\text { Complex, need the sampling and } \\
\text { conservation of indigenous consortium } \\
\text { without depressurization. }\end{array}$ & $\begin{array}{l}\text { The most complex, need time at sea, ROV } \\
\text { or lander with isobaric pressurized sampling } \\
\text { apparatus and pressurized incubator with } \\
\text { isobaric ship-to-lab transfer system. }\end{array}$ & Expensive & $\begin{array}{l}\text { Chemicals of known and } \\
\text { unknown compositions }\end{array}$ & Ideal \\
\hline $\begin{array}{l}\text { 2. In situ incubation with an } \\
\text { indigenous consortium }\end{array}$ & $\begin{array}{l}\text { Relatively complex, generally need the use } \\
\text { of radiolabeled incubation products to } \\
\text { measure accurately degradation products in } \\
\text { the microbiological biomass and avoid } \\
\text { artifacts (e.g. local recontamination). }\end{array}$ & $\begin{array}{l}\text { Complex, need the deployment of ROV or } \\
\text { landers at sea during a long period of time } \\
\text { and possibly the handling of radiolabeled } \\
\text { products. }\end{array}$ & Expensive & $\begin{array}{l}\text { Chemical of already known } \\
\text { composition in order to } \\
\text { synthesize radiolabeled } \\
\text { similar products. }\end{array}$ & $\begin{array}{l}\text { Good but } \\
\text { restricted to well- } \\
\text { characterized } \\
\text { pollutants }\end{array}$ \\
\hline $\begin{array}{l}\text { 3. Cultivation of pure } \\
\text { piezotolerant strains }\end{array}$ & $\begin{array}{l}\text { Relatively simple, just need the isolation or } \\
\text { the purchase of relevant piezotolerant pure } \\
\text { strains to work in lab. }\end{array}$ & $\begin{array}{l}\text { Classical lab pressurized incubators with the } \\
\text { possibility to realize a control incubation } \\
\text { under atmospheric pressure, time at sea not } \\
\text { mandatory. }\end{array}$ & Affordable & $\begin{array}{l}\text { Chemicals of known and } \\
\text { unknown compositions }\end{array}$ & Very good \\
\hline
\end{tabular}

